\title{
Methodology for Detecting Trace Amounts of Microchimeric DNA from Peripheral Murine White Blood Cells by Real-Time PCR
}

\author{
Carol M. Artlett ${ }^{1}$, C. Gennaro Dito ${ }^{1}$ and Paul J. Christner ${ }^{1 *}$ \\ ${ }^{1}$ Division of Rheumatology, Thomas Jefferson University, Philadelphia, PA 19107 USA \\ *To whom correspondence should be addressed: Paul Christner, Division of Rheumatology, Thomas Jefferson University, $233 \mathrm{~S}$ \\ $10^{\text {th }}$ Street, Room 509 B.L.S.B., Philadelphia, PA, 19107, USA. E-mail: Paul.Christner@mail.tju.edu
}

Submitted: January 17, 2003; Revised: March 5, 2003; Accepted: March 9, 2003; Published: April 7, 2003

Indexing terms: Polymerase Chain Reaction, DNA, Mice, T-Lymphocytes, leukocytes.

\begin{abstract}
Real-time PCR methodology can successfully quantitate microchimeric cell populations at a concentration of 100 microchimeric cells/100,000 host cells; however, it has not been successful in quantitating DNA from trace numbers of microchimeric white blood cells which we reported are present in murine peripheral blood at a concentration as low as $2 / 100,000$ host cells. We report methodology using primers for a portion of the $\mathrm{H} 2-\mathrm{k}^{\mathrm{b}}$ murine histocompatibility sequence, specific for the C57BL/6J mouse. When these primers were used in the presence of $11,000 \mu \mathrm{M}$ primer, a 20 -fold increase in the median manufacturer's recommended concentration, the assay could be optimized to detect $34 \mathrm{pg}$ of C57BL/6J DNA in a background of $2.5 \mu \mathrm{g}$ of carrier BALB/cJ DNA $(1 / 100,000)$. These conditions resulted in a detection limit half as sensitive as that found when no carrier DNA was present.
\end{abstract}

\section{INTRODUCTION}

Microchimeric cells are cells found in the blood circulation of one individual (the mother) but derived from another individual (the fetus) (1). Some of these cells, T-lymphocytes, are long lived and have been identified in a mother's circulation 40 years after her last pregnancy (2). Real-time PCR has been successfully employed to detect the presence of microchimeric fetal cell DNA for prenatal diagnosis in plasma and serum $(3,4)$. The technique has been used to identify fetuses having the following diseases: Downs syndrome (5) and $\mathrm{RhD}$ status (6). However, the detection of trace numbers of microchimeric cell DNA from whole peripheral blood mononuclear cell DNA has been confounded by the fact that the sensitivity of the real-time PCR assay decreases if the starting concentration of DNA in the reaction is very high (7). Ordinarily, if there were not enough DNA from the microchimeric cells in a given sample, then the amount of sample to be assayed would be increased to a level that was high enough to bring the total number of copies of microchimeric DNA to a minimum threshold level which could be amplified and detected by real-time PCR. However, from our own observations, it is clear that the real-time PCR amplification loses sensitivity when the total amount of DNA in the assay tube is increased. Byrne et al. (7) reported a realtime PCR technique that detected chimeric cells in the peripheral blood from transplanted mice. Their technique employed the zfy2 gene in the murine genome, which contained four copies of the target template per male cell. They reported an excellent limit of sensitivity for their assay of 6 copies of target DNA in $40 \mathrm{ng}$ of background DNA. If we accept the published value of $6^{2} / 3$ picograms (pg) of DNA per cell (8), then Byrne et al. (7) were able to detect 6 copies of male DNA in a background of DNA from 6000 cells.

Unfortunately, the detection of fetal microchimeric cells in post-partum murine blood samples requires even more sensitivity than that published by Byrne et al. (7). In the microchimeric retired breeder mice, which were investigated in our laboratory, we found that the microchimeric cells were present in concentrations of 0.00002 to $0.005 \%$ of the total white cell population (9). Most of this range is significantly less than one copy of microchimeric DNA in $40 \mathrm{ng}$ of background DNA. Therefore, it was necessary to modify the manufacturer's recommended assay conditions and develop a method to reliably assay samples containing as much as $2.5 \mu \mathrm{g}$ of DNA. Here we describe a real-time PCR assay that is sensitive enough to quantitate the number of fetal microchimeric cells in

(C) 2003. Biological Procedures Online. Published in Biological Procedures Online under license from the author(s). Copying, printing, redistribution and storage permitted. 
a background of maternal DNA purified from post-partum mouse peripheral blood mononuclear cells.

\section{MATERIALS AND METHODS}

\section{Animals}

Virgin female BALB/cJ mice, aged 2 months and female $\mathrm{BALB} / \mathrm{cJ}$ retired breeders (bred to male $\mathrm{C} 57 \mathrm{BL} / 6 \mathrm{~J}$ or BALB/cJ mice) and aged 7-8 months were purchased from The Jackson Laboratory (Bar Harbor, ME). These animals had been bred multiple times to $\mathrm{C} 57 \mathrm{BL} / 6 \mathrm{~J}$ males and had delivered a minimum of 4 litters before being retired. Animals were housed at the Thomas Jefferson University animal facility, which is approved by the American Association for Accreditation of Laboratory Animal Care (AAALAC). All protocols were reviewed and approved by the Thomas Jefferson University Animal Care and Use Committee.

\section{DNA isolation}

Blood was obtained by intraocular bleeding into a tube containing $0.1 \mathrm{M}$ EDTA, $\mathrm{pH} 8.0$, to prevent clotting. DNA was extracted according to the following method. The red cells were lysed in $1.3 \mathrm{ml} 0.144 \mathrm{M} \mathrm{NH} \mathrm{Nl}_{4} \mathrm{Cl} / 100 \mathrm{mM} \mathrm{NaHCO}$. The tubes were centrifuged at $3000 \mathrm{rpm}$ and the supernatant removed. The white cells were washed two to three times in $0.144 \mathrm{M} \mathrm{NH} \mathrm{N}_{4} \mathrm{Cl} / 100 \mathrm{mM} \mathrm{NaHCO}$ or until the supernatant was no longer red. The remaining cells were then centrifuged and the supernatant removed. White cells were resuspended in 300 $\mu 10.01 \mathrm{M}$ Tris ( $\mathrm{pH} 8.0) / 0.4 \mathrm{M} \mathrm{NaCl} / 0.002 \mathrm{M}$ EDTA $(\mathrm{pH} 8.0$ ) and $20 \mu 10 \%$ SDS and incubated at room temperature with shaking until all the cells had lysed. The released DNA was purified by precipitation with $100 \mu \mathrm{l}$ saturated $\mathrm{NaCl}$ and $300 \mu \mathrm{l}$ chloroform with vigorous shaking and centrifugation. The clear aqueous layer was transferred to a tube and the DNA precipitated in 2 volumes of ethanol. The DNA was collected with a disposable inoculating needle into $100 \mu 110 \mathrm{mM}$ Tris$\mathrm{HCl}(\mathrm{pH} 8.0) / 1 \mathrm{mM}$ EDTA ( $\mathrm{pH} 8.0)$. The DNA was analyzed on a spectrophotometer at $260 \mathrm{~nm}$ and adjusted to a final concentration of $500 \mathrm{ng} / \mu \mathrm{l}$.

\section{Real-time PCR amplification of microchimeric C57BL/6J DNA}

Custom primers were obtained from Research Genetics (Huntsville, AL) and were designed to specifically amplify a sequence of the IgG sequence unique to the C57BL/6J (10) genome (forwards primer: 5'-CAAAGTCTCCAAGCCCT-3'; reverse primer: 5'-GACTTACCTGCGCATGG-3'). The amount of each primer used varied and is stated in the figure legends below. A custom Taqman probe was used, specific to the same sequence on the $\mathrm{C} 57 \mathrm{BL} / 6 \mathrm{~J}$ genome, 5'-(FAM)TCGAGTAACCCCCAGCCTTCTCTCTGC-TAMRA)-3' at a concentration of $100 \mu \mathrm{M}$. All PCR amplifications were performed in duplicate and each analysis contained positive controls of C57BL/6J DNA and negative controls of BALB/cJ DNA. The default real-time PCR assay conditions were employed according to the Applied Biosystems recommendations for 45 cycles (11). The break through cycle (threshold) was automatically set at 10 standard deviations above the mean baseline fluorescence at a point where the amplification process had reached the exponential phase. A standard curve was obtained simultaneously as unknown samples were processed. All standard curves had a slope of at least -3.4 and an R-coefficient (efficiency) of greater than 0.98. The curve was prepared by serial diluting C57BL/6J DNA to the following concentrations $0,34,102,309$, and 926 pg per assay tube. The $\mathrm{C} 57 \mathrm{BL} / 6 \mathrm{~J}$ DNA was diluted into water or into BALB/cJ DNA such that the final concentration of BALB/cJ was $2.5 \mu \mathrm{g}$ per assay tube. The Taqman amplification reactions were adjusted to a final volume of $50 \mu \mathrm{l}$ using the TaqMan ${ }^{\circledR}$ Universal PCR Master Mix. Each reaction contained $25 \mu \mathrm{l}$ Taqman reaction buffer, comprising of $4 \mathrm{mM} \mathrm{MgCl}_{2}, 200 \mu \mathrm{M}$ each dATP, dCTP, and dGTP; $400 \mu \mathrm{M}$ dTTP; $1.25 \mathrm{U}$ AmpliTaq Gold; 0.5U AmpErase. Five-microliters of unknown DNA $(2.5 \mu \mathrm{g})$ was added to each reaction tube.

\section{Anti-contamination procedures}

Strict precautions against contamination of the DNA and during PCR assays were employed. Separate laboratory areas were used to extract DNA, set up PCR reactions, carry out the amplifications, and analyze the PCR products by gel electrophoresis. As a negative control for the amplification of $Y$ chromosome, two nulligravid females were used. Aerosol resistant pipette tips were used to handle all solutions. No evidence of cross contamination of any samples was observed using these methods, as we never detected an allele in a blank sample.

\section{RESULTS AND DISCUSSION}

From previous published work in which we had developed a semi-quantitative method for detecting trace amounts of murine fetal DNA in maternal peripheral blood DNA (9), it was clear that to detect the DNA from the very small population of microchimeric cells, it would be necessary to improve the sensitivity of the real-time PCR assay so successful PCR amplification could occur when assaying a sample containing microgram quantities of DNA. Initially, serial dilutions of C57BL/6J DNA were made into water at 0 , $34,102,309$, and $926 \mathrm{pg}$ and analyzed by real-time PCR. Following the manufacturer's recommended protocol (11), the assay was optimized for $900 \mu \mathrm{M}$ of each forward and reverse primer and $100 \mu \mathrm{M}$ of the probe. Using DNA purified from the peripheral blood of a $\mathrm{C} 57 \mathrm{BL} / 6 \mathrm{~J}$ mouse, these conditions yielded a reproducible standard curve (Fig. 1A) when the DNA samples were diluted in water. Thirty-four picograms of DNA was the lowest reliable point on this curve. When the C57BL/6J DNA samples were assayed under the same 
manufacturer's recommended conditions but in the presence of $2.5 \mu \mathrm{g}$ of $\mathrm{BALB} / \mathrm{cJ}$ carrier DNA, the sensitivity of the realtime PCR reaction was essentially eliminated (Fig. 1A). Even at the highest concentration of C57BL/6J DNA (926 pg) less than 5 cell equivalent $(34 \mathrm{pg}$ ) of product could be detected. In Figure 1B the $\log$ of the C57BL/6J DNA concentration is plotted against the PCR threshold cycle number (cycle at which product was first detectable). It can be seen in this figure that the presence of $2.5 \mu \mathrm{g}$ of BALB/cJ DNA depressed the PCR reaction by 4.3 to 6 cycles, which represents a depression of 20 to 64 fold. $2.5 \mu \mathrm{g}$ of BALB/cJ DNA was selected because using that amount of DNA would allow us to detect 5 microchimeric cell equivalents in a background of 375,000 cells, a level compatible with what we have found in murine blood (9). The discovery, that $2.5 \mu \mathrm{g}$ of BALB/cJ DNA reduced the sensitivity of the real-time PCR, explained why we were unable to detect significant numbers of microchimeric cells by real-time PCR in our test samples.

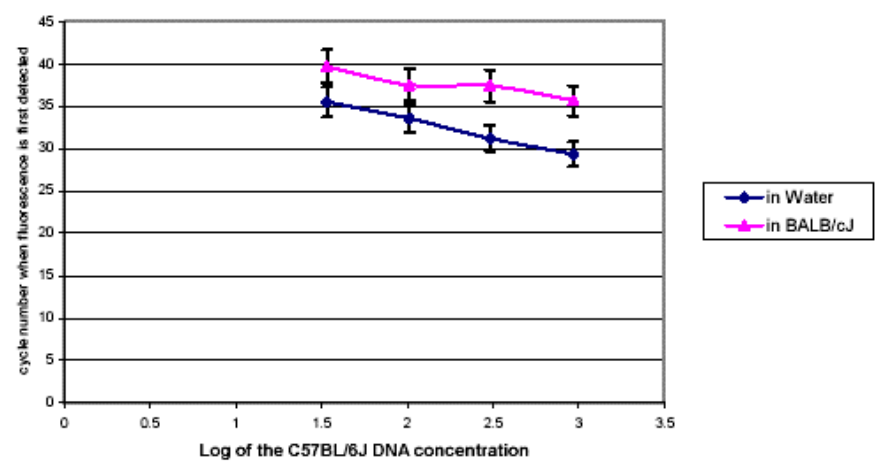

Fig. 1: A real-time PCR assay in which a C57BL/6J strain-specific DNA sequence was amplified in the presence or absence of $2.5 \mu \mathrm{g}$ of BALB/cJ DNA using the highest recommended manufacturer's primer concentration. The figure plots the cycle number at which fluorescence was first detected (breakthrough cycle) against the $\log$ of the concentration of the C57BL/6J DNA. From this plot it is possible to quantitate the effect of the carrier DNA on the sensitivity of the assay, because, if the breakthrough cycle number increases by one, the sensitivity decreases by half. The average increase in breakthrough cycle number between the curves was 5.5 to 6.5 cycles indicating a loss of sensitivity of 64 fold. Clearly these conditions were inadequate to identify trace amounts of C57B16/J DNA in a high background of BALB/cJ DNA.

Although we did not completely understand why the large amount of BALB/cJ DNA should lead to such a dramatic decrease in the sensitivity of the real-time PCR for the trace amounts of the C57BL/6J DNA sequence, we hypothesized that the decrease in sensitivity might be due to non-specific binding of the primers to the BALB/cJ DNA and therefore these reagents would not be available to bind to the correct C57BL/6J DNA sequence. To test this hypothesis, we performed real-time PCR reactions at $11,000 \mu \mathrm{M}$ approximately 12 times the manufacturer's highest recommended concentration of each primer. The results of these assays are shown in Figure 2. It can be seen that there was a reversal of the loss of sensitivity when $11,000 \mu \mathrm{M}$ of each primer was used, compared to $900 \mu \mathrm{M}$ of each primer. At $11,000 \mu \mathrm{M}$ primer concentration, the cycle number at which PRC product could first be detected was delayed by 1 cycle representing a depression of sensitivity of 50 percent compared to the value obtained when the C57BL/6J DNA was assayed without carrier BALB/cJ DNA. To determine if the $11,000 \mu \mathrm{M}$ concentration of each primer was the optimal concentration for assaying $2.5 \mu \mathrm{g}$ of DNA, the real-time PCR reaction was performed at $900,2200,5500,11,000,16,500$ and $22,000 \mu \mathrm{M}$ primer concentration. The results are shown in Figure 3. It can be seen that the sensitivity of this assay increases with primer concentration until it reached a maximum at or around 11,000 $\mu \mathrm{M}$ of primer and then falls off above that point. Although $11,000 \mu \mathrm{M}$ of primer was the optimal concentration of primer, of the concentrations tested, it appears that any concentration between 2200 and $11,000 \mu \mathrm{M}$ of primer would produce acceptable results.

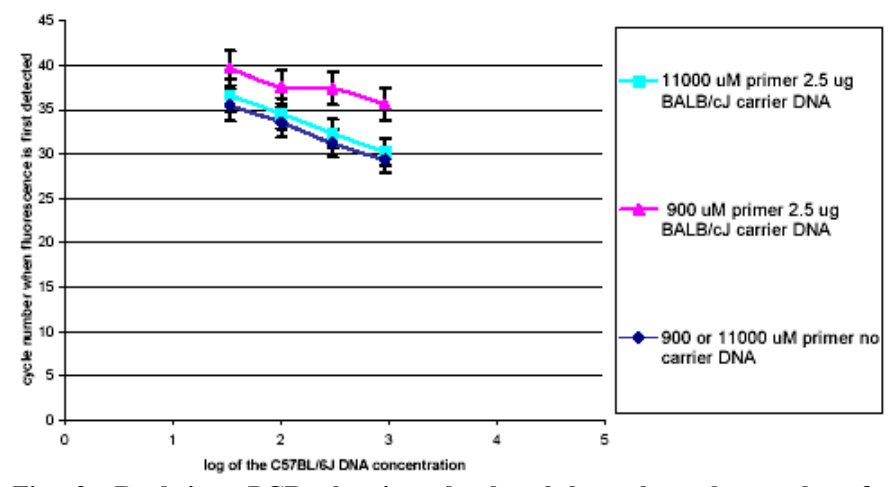

Fig. 2: Real-time PCR showing the breakthrough cycle number for amplification of a C57BL/6J strain specific DNA sequence. The PCR was performed with the amounts of primer and carrier BALB/cJ DNA as shown The figure indicates that in the presence of $11,000 \mathrm{uM}$ primer the breakthrough cycle number is decreased by 3.5 to 5.5 cycles in the presence of $2.5 \mathrm{ug}$ of carrier DNA. By comparing the two lower graph lines, it can be seen that the presence of carrier DNA at 11,000 uM carrier concentration only causes the breakthrough Cycle number to increase by approximately 1 cycle, indicating that in the presence of $11,000 \mathrm{uM}$ carrier the sensitivity of the assay is only decreased by half instead of 64 fold when using the manufacturer's recommended concentration for primers.

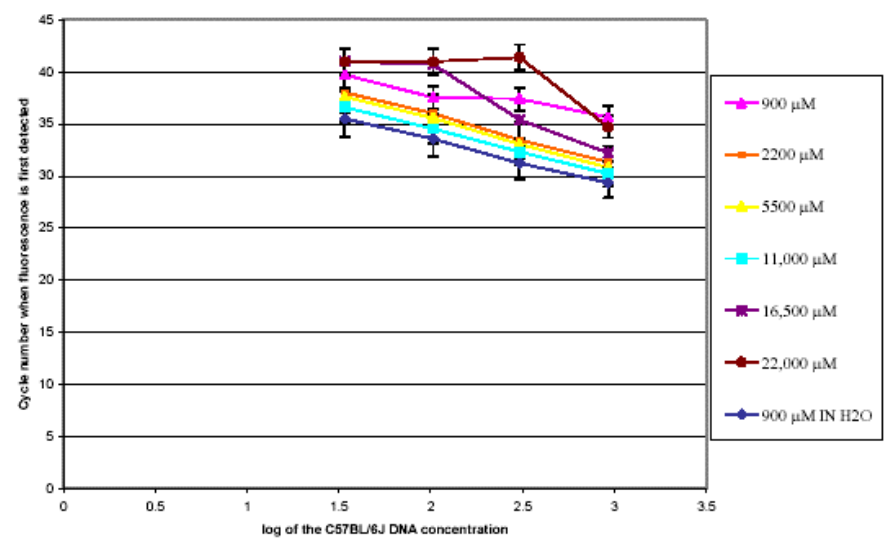

Fig. 3: Real-time PCR showing the breakthrough cycle number for amplification of a C57BL/6J strain specific DNA sequence. The PCR was performed with primer amounts varying from 900 to $22,000 \mu \mathrm{M}$ in the presence of $2.5 \mu \mathrm{g}$ of BALB/cJ DNA unless otherwise noted. This figure shows that the optimal primer concentration for detection of C57BL6/J DNA in the presence of $2.5 \mathrm{ug}$ of BALB/cJ carrier DNA is 11,000 uM (---- line), because this line has the lowest breakthrough cycle number except for the control performed with no carrier DNA (------ in $\mathrm{H}_{2} \mathrm{O}$ ). However, it should be noted that given an error range of $5-10 \%$ for these assays that primer concentrations between 2200 
and $11,000 \mathrm{uM}$ are equally affective in optimizing the assay for detection of trace mircochimeric C57BL/6J DNA in 2.5 ug of BALB/cJ DNA.

Experiments to optimize the probe concentration were not carried out, because the probe is much more costly than the primers and the probe would be expected to bind more specifically than the primers because it is $27 \mathrm{bp}$ in length and the primers are only $17 \mathrm{bp}$. However, we did perform one experiment in which the probe concentration was increased 5 fold to $500 \mu \mathrm{M}$. There was no dose response correlation between the amount of C57BL/6J DNA added to the assay tube and the fluorometric response observed with the Taqman real-time PCR machine at $500 \mu \mathrm{M}$ (data not shown) and the effect of changing the probe concentration from that recommended by the manufacturer (11) was not investigated further.

Although the real-time PCR analysis has been used previously for the detection of nucleic acids in a limited quantity of starting material, the detection of trace DNA sequences in large quantities of carrier genomic DNA has been confounded by the problems elucidated above. These results suggest that the limitations in the sensitivity of the real-time PCR assay caused by large amounts of carrier DNA can be overcome by using forward and reverse primers at concentrations higher than that recommended by the manufacturer. Under these conditions, the assay was sensitive enough to detect $34 \mathrm{pg}$ of DNA (5 cell equivalents) in $2.5 \mu \mathrm{g}$ of maternal DNA. We have found this method to be approximately 50 times more sensitive than the method reported by Byrne et al. (7) who reported detecting 6 cell equivalents in up to 40 ng of DNA.

The decrease in sensitivity to $50 \%$ of the values found, when no carrier DNA was present, was acceptable for our purposes of detecting microchimeric DNA in murine peripheral blood. We were able to detect the presence of 5 microchimeric cells in a background of 375,000 host cells which is approximately 1 cell equivalent in 75,000 cells. In addition, the conditions for an optimal real-time PCR amplification in the presence of microgram quantities of DNA are most likely, in part, dependent on the particular set of primers and the probe selected. Therefore, optimization assays should be performed with each set of reagents to determine the proper concentrations for each. 


\section{REFERENCES}

1. Artlett CM, Smith JB, Jimenez SA. Identification of fetal DNA and cells in skin lesions from women with systemic sclerosis. N Eng J Med 1998; 338:1186-1191.

2. Artlett CM, Cox LA, Ramos RC, Dennis TN, Fortunato RA, Hummers LK, Jimenez SA, Smith JB. Increased microchimeric CD $+\mathrm{T}$ lymphocytes in peripheral blood from women with systemic sclerosis. Clin Immunol 2002; 103:303-308.

3. Hahn S, Zhong XY, Burk MR, Troeger C, Holzgreve W. Multiplex and real-time quantitative PCR on fetal DNA in maternal plasma. A comparison with fetal cells isolated from maternal blood. Ann NY Acad Sci 2000; 906:148152.

4. Lo YMD, Tein MSC, Lau TK, Haines CJ, Leung TN, Poon PMK, Wainscoat JS, Johnson PJ, Chang PMZ, Hjelm NM. Quantitative analysis of fetal DNA in maternal plasma and serum: implications for noninvasive prenatal diagnosis. Am J Hum Genet 1998; 62:768-775.

5. Poon LL, Leung TN, Lau TK, Lo YM. Prenatal detection of fetal Down's syndrome from maternal plasma. Lancet 2000; 356:1819-1820.
6. Lo YM, Hjelm NM, Fidler C, Sargent IL, Murphy MF, Chamberlain PF, Poon PM, Redman CW, Wainscoat JS. Prenatal diagnosis of fetal $\mathrm{RhD}$ status by molecular analysis of maternal plasma. N Eng J Med 1998; 339:1734-1738

7. Byrne P, Huang W, Wallace VM, Shean MK, Zhang Z, Zhong Q, Theodossiou C, Blakesley H, Kolls JK, Schwarzenberger P. Chimerism analysis in sexmismatched murine transplantation using quantitative realtime PCR. Biotechniques 2002; 32:276-286.

8. Saiki RK, Gelfand DH, Stoffel S, Scharf SJ, Higugchi R, Horn GT, Mullis KB, Erlich HA. Primer-directed enzymatic amplification of DNA with a thermostable DNA polymerase. Science 1988; 239:487-491.

9. Christner PJ, Artlett CM, Conway RF, Jimenez SA. Increased numbers of microchimeric cells of fetal origin and dermal fibrosis in mice following injection of vinyl chloride. Arthritis Rheum 2000; 43:2598-2605.

10. Ollo R, Rougeon F. Gene conversion and polymorphism: generation of mouse immunoglobulin gamma $2 \mathrm{a}$ chain alleles by differential gene conversion by gamma $2 \mathrm{~b}$ chain gene. Cell 1983; 32:515-523.

11. A.B.W.S. (Applied Biosystems Web Site) http://docs.appliedbiosystems.com/pebiodocs/04304449.p df 